\title{
Meat fatty acid composition as affected by fatness and genetic factors: a review
}

\author{
Stefaan DE SMET*, Katleen RAES, Daniel DEMEYER \\ Department of Animal Production, Faculty of Agricultural and Applied Biological Sciences, Ghent \\ University, Proefhoevestraat 10, 9090 Melle, Belgium
}

(Received 13 December 2002; accepted 9 January 2004)

\begin{abstract}
Meat fatty acid composition is influenced by genetic factors, although to a lower extent than dietary factors. The species is the major source of variation in fatty acid composition with ruminant meats being more saturated as a result of biohydrogenation in the rumen compared to the meat of monogastric animals. The level of fatness also has an effect on the meat fatty acid composition. The contents of saturated (SFA) and monounsaturated (MUFA) fatty acids increase faster with increasing fatness than does the content of PUFA, resulting in a decrease in the relative proportion of PUFA and consequently in the polyunsaturated/saturated fatty acids (P/S) ratio. The dilution of phospholipids with triacylglycerols and the distinct differences in fatty acid composition of these fractions explain the decrease in the $\mathrm{P} / \mathrm{S}$ ratio with increasing fatness. An exponential model was fitted to the literature data for beef and showed a sharply increasing P/S ratio at low levels of intramuscular fat. Lowering the fat level of beef is thus more efficient in increasing the $\mathrm{P} / \mathrm{S}$ ratio than dietary interventions. For pork, the intramuscular fat level also affects the P/S ratio, but nutrition will have a larger impact. The fat level also influences the n-6/n-3 PUFA ratio, due to the difference of this ratio in polar and neutral lipids. However, these effects are much smaller than the effects that can be achieved by dietary means. Differences in fatty acid composition between breeds and genotypes can be largely explained by differences in fatness. However, after correction for fat level, breed or genotype differences in the MUFA/SFA ratio and in the longer chain C20 and C22 PUFA metabolism have been reported, reflecting the possible genetic differences in fatty acid metabolism. Breed differences in meat conjugated linoleic acid (CLA) content have not yet been reported, but the c9t11CLA content in meat is positively related to the total fat content. Heritabilities and genetic correlations for the proportion of certain fatty acids have been estimated in a few studies, and correspond to the observations at the phenotypic level in relation to the intramuscular fat level. Although there is potential for genetic change, incorporating fatty acid composition as a goal in classical breeding programs does not seem worthwhile at the present. Enzyme activities have been measured in a few studies, but are not able to explain between-animal variation in fatty acid composition. Biochemical and molecular genetic studies should be encouraged to unravel the mechanisms responsible for differences in the metabolism and incorporation of specific fatty acids in meat.
\end{abstract}

fatty acids / meat / genetics / P/S ratio

\footnotetext{
* Corresponding author: stefaan.desmet@UGent.be
} 
Résumé - Influence des facteurs génétiques et de l'état d'engraissement sur la composition en acides gras de la viande. Revue. La composition en acides gras de la viande est affectée par divers facteurs : des facteurs nutritionnels, mais aussi des facteurs génétiques, quoiqu'à un degré moindre. L'espèce animale est également une source de variation importante, c'est même la plus importante. La viande des ruminants est plus riche en acides gras saturés que celle des monogastriques, en raison de la biohydrogénation dans le rumen. L'état d'engraissement a aussi un effet très net sur la composition en acides gras. La teneur en acides gras saturés (AGS) et monoinsaturés (AGMI) croît plus rapidement que celle en acides gras polyinsaturés (AGPI) lorsque l'état d'engraissement augmente, ce qui résulte en une diminution de la proportion des AGPI et par conséquent un rapport acides gras polyinsaturés/saturés $(\mathrm{P} / \mathrm{S})$ amoindri. Cette baisse du rapport $\mathrm{P} / \mathrm{S}$ associée à une augmentation du taux de gras intramusculaire peut s'expliquer par la diminution du rapport phospholipides/triglycérides dans les lipides totaux et la composition en acides gras différente de ces deux fractions. Un modèle exponentiel a été adapté aux données de la littérature pour la viande de boeuf et a montré une augmentation nette du rapport P/S lorsque les teneurs en gras intramusculaire sont faibles. La diminution de la teneur en lipides de la viande de boeuf est donc plus efficace pour augmenter le rapport $\mathrm{P} / \mathrm{S}$ que l'intervention de paramètres nutritionnels. Pour la viande de porc, le taux de gras intramusculaire a également un effet sur le rapport P/S, mais les facteurs nutritionnels auront un effet plus prononcé. Le taux de gras intramusculaire peut aussi influencer le rapport n-6/n-3 AGPI, en raison des différences dans ce rapport entre les phospholipides et les triglycérides. Néanmoins, cet effet est beaucoup moins important que les effets qui peuvent être obtenus avec les paramètres nutritionnels. La mise en évidence de différences dans la composition en acides gras entre les races et les génotypes peut s'expliquer en grande partie par la variabilité de l'état d'engraissement. Cependant, en introduisant un facteur correctif correspondant au dépôt de gras, des différences entre races et génotypes persistent pour le rapport AGMI/AGS et pour le métabolisme des acides gras à chaîne longue (C20 et C22), reflétant de possibles dissemblances génétiques dans le métabolisme des acides gras. Entre races, aucune différence n'a été rapportée, à ce jour, pour la teneur en acides linoléiques conjugués (ACL), mais le taux de l'isomère cis-9 trans-11 dans la viande semble être positivement corrélé à la teneur en gras total. Des études ont estimé les héritabilités et les corrélations génétiques pour les proportions de certains acides gras ; elles correspondent à des observations phénotypiques en relation avec le taux de gras intramusculaire. Bien qu'il existe un potentiel génétique pour modifier la composition en acides gras intramusculaires, l'intégration de la composition en acides gras comme critère dans les programmes de sélections génétiques ne semble pas intéressante actuellement. Quelques études ont mesuré les activités enzymatiques, mais elle n'ont pas permis d'expliquer la variabilité entre animaux dans la composition en acides gras. Des études biochimiques et moléculaires doivent être engagées afin de décrypter les mécanismes responsables des différences dans le métabolisme et l'incorporation d'acides gras spécifiques dans la viande.

acides gras / viande / génétique / rapport polyinsaturés / saturés

\section{INTRODUCTION}

For many years, fatty acid composition in meat producing animals has received considerable interest in view of its implications for human health and for meat quality characteristics [24, 92, 93]. Like most animal production traits, fatty acid composition is influenced by both genetic and environmental factors. The latter includes management but mainly feeding, explaining why the majority of studies attempting to achieve fatty acid profiles in meat that correspond better to current human nutrition guidelines, have dealt with animal feeding (see e.g. reviews $[14,35,56]$ ). It is well known that large changes in fatty acid composition can be brought about by altered feeding strategies, especially in monogastric animals. However, genetic factors have been investigated far less, although several studies have reported breed differences for fatty acid composition in different farm animal species, and a few have reported estimates of genetic parameters.

In this paper, an attempt was made to review genetic effects on muscle fatty acid composition. Information was restricted to the major fatty acids in intramuscular fat 
and to some indices used in relation to human health considerations, i.e. the $\mathrm{P} / \mathrm{S}$ ratio (calculated as (C18:2n-6 + C18:3n-3)/ $(\mathrm{C} 14: 0+\mathrm{C} 16: 0+\mathrm{C} 18: 0)$ and the $n-6 / n-3$ ratio (calculated as the sum of n-6 PUFA/ the sum of n-3 PUFA). It should be noted that the longer chain PUFA (C20-C24) are not included in the $\mathrm{P} / \mathrm{S}$ ratio, but are in the n-6/n-3 ratio as presented here. Recent studies were mainly used because these generally report more detailed fatty acid analyses, but breed differences and related matters have already been investigated in older studies (e.g. for beef $[15,16,64]$ and for pork [4]).

It should be realised that fatty acid composition differs between various tissues, including intra- and intermuscular, as well as abdominal (e.g. perirenal, omental) and subcutaneous adipose tissue, as has been examined e.g. for beef cattle by several authors $[1,15,49,90]$. The level of saturation normally increases with increasing distance from the animal's exterior, but there is additional variability between similarly located muscles or subcutaneous fat depots. In this paper, emphasis was placed on muscle fatty acid composition, because intramuscular fat cannot be removed before consumption and thus inevitably has an impact on human health. However, more generally the fatty acid composition of other fat depots, especially the backfat of pigs, also deserves attention because of its considerable contribution to total fat intake from meat products in the Western diet.

\section{GENETIC VARIABILITY}

Genetic variability consists of differences between species, differences between breeds or lines, differences due to the crossing of breeds and differences between animals within breeds. The latter source of variation is estimated by heritabilities and genetic correlations. Breed effects may be influenced by the segregation of major genes, of which the double-muscled gene in cattle and the stress sensitivity gene in pigs are well known examples. It is sometimes dif- ficult to assess the real contribution of genetics to differences in fatty acid composition. Breed comparisons are often confounded by other effects like fat level, live weight or age at slaughter and production system, as shown e.g. for lamb meat $[22,75]$.

It is clear that the species is the major source of variation in meat fatty acid composition. Beef and lamb normally have a low $\mathrm{P} / \mathrm{S}$ ratio compared with pork because of the biohydrogenation of unsaturated fatty acids in the rumen. Enser et al. [18] found that for steaks and chops purchased from supermarkets in the UK the mean $\mathrm{P} / \mathrm{S}$ ratio is $0.11,0.15$ and 0.58 for beef, lamb and pork respectively and is more favourable for pork. On the contrary, the n- $6 / n-3$ ratio is more favourable for beef and lamb compared to pork $(2.11,1.32$ and 7.22 respectively). However, these mean values may vary largely depending on genetic and feeding factors and should thus not be generalised. Each of the sources of genetic variation mentioned above will be dealt with in the next sections, but because of its importance, the relationship between carcass fat level and meat fatty acid composition will be examined initially.

\section{EFFECT OF FAT LEVEL}

Reducing carcass fatness has been one of the major breeding goals for farm animals for many years. Fat deposition is highly heritable and, depending on the emphasis that is put on this trait relative to other selection traits, breeds and animals within breeds may strongly differ in their mean carcass and meat fat content $[50,79,85]$. In this respect, phenotypic and genetic correlations between carcass fatness and intramuscular fat content are also important. For cattle and pigs, these have been estimated at moderate positive levels, indicating that reductions in carcass fatness as a result of selection are likely to be accompanied by lower intramuscular fat levels, but still allowing considerable variability in intramuscular fat content independent of carcass fatness. Since fat deposition is determined 
by de novo fatty acid synthesis and the uptake of exogenous fatty acids [87], it is worthwhile examining the effect of variation in fatness on the meat fatty acid composition within and between breeds. Differences in fat content and fatty acid composition between muscles and muscle types also have to be accounted for. Another factor with a large effect on fatness is sex [56]. In cattle, the order of leanness in young slaughter animals is normally bulls $>$ steers $>$ heifers. In slaughter pigs, it is boars $>$ gilts $>$ barrows. Differences in maturity, age and/ or live weight at slaughter further contribute to differences in fatness.

Growth and fattening of meat animals is associated with an increase in fat deposition, first in subcutaneous and later in intramuscular fat [87]. Nürnberg et al. [57] studied the intramuscular fatty acid composition in three different cattle breeds (German Holstein, Galloway and Belgian Blue) during growth. Growth from birth to slaughter at 24 months was accompanied by an increase in the intramuscular fat content and a continuous increase in the proportion of saturated fatty acids during growth. At
18 months of age, the Belgian Blue animals contained the lowest amount of subcutaneous fat and the lowest intramuscular fat content, while at birth the Galloway calves contained the highest intramuscular n-3 fatty acid content. During early growth (until 4-6 months of age), the intramuscular n-3 content increased for the three breeds followed by a continuous decrease afterwards. These results suggest age- and breed-dependent differences in the deposition of some fatty acids. Also, the study demonstrated that breed effects are related to well-known differences between breeds in the overall capacity for fat deposition.

\subsection{Effect on $\mathrm{P} / \mathrm{S}$ ratio}

Variation in fat content has an effect on fatty acid composition, independent of species or breed and dietary factors. The content of saturated fatty acids (SFA) and MUFA increases faster with increasing fatness than does the content of PUFA, leading to a decrease in the relative proportion of PUFA and consequently in the P/S ratio. This is shown in Figure 1 for samples from

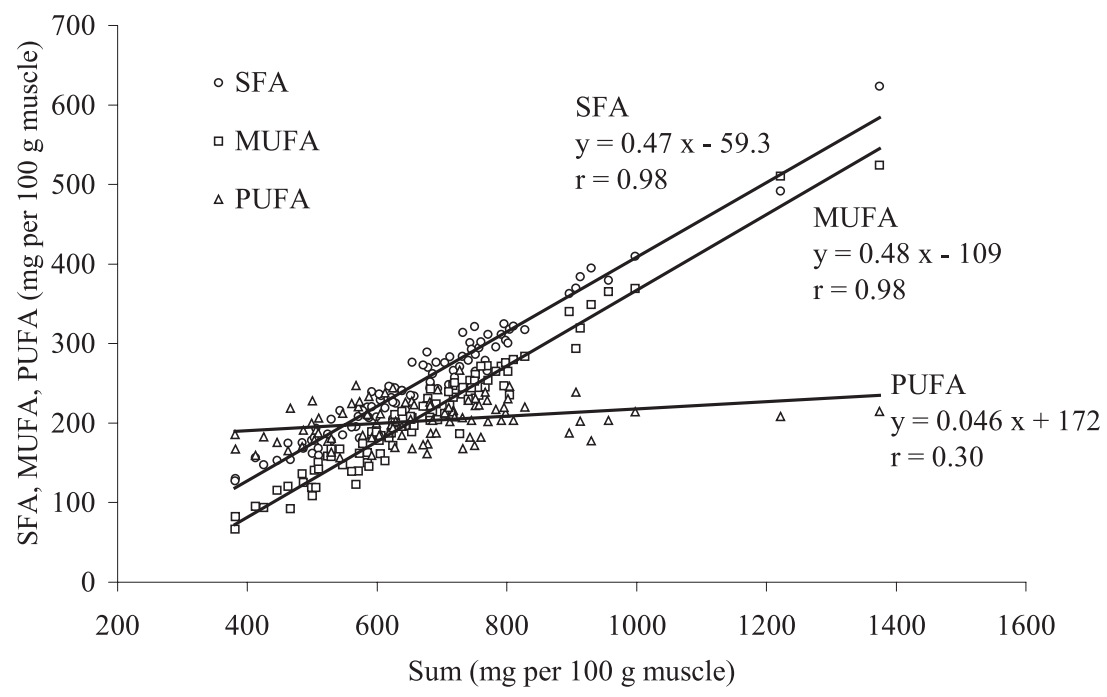

Figure 1. Relationships between the SFA, MUFA and PUFA content and their sum (mg per $100 \mathrm{~g}$ muscle) in intramuscular fat of Belgian Blue double-muscled bulls (data obtained from [68]). 


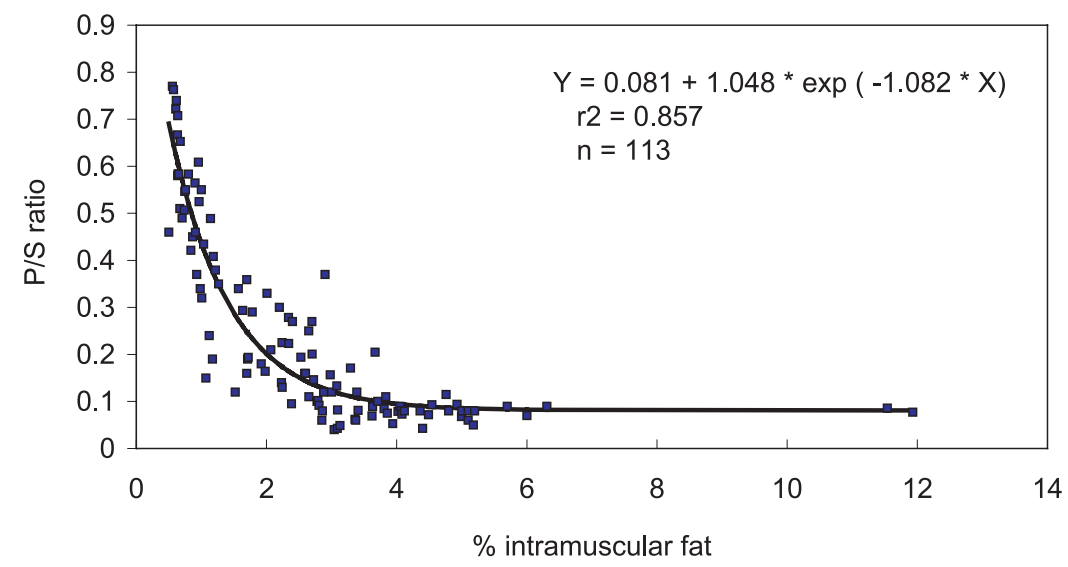

Figure 2. Relationship between the P/S ratio and intramuscular fat level in beef. Each point represents a treatment mean value from one of the following references: $[8,11,18,19,23,34,38$, $39,44,48,49,53,57,58,66,68-70,74,76,83,86,90,96]$.

different muscles from a group of doublemuscled bulls fed different diets (data from [68]). Similar findings are reported for pork $[4,72]$ and sheep $[55,58]$. A clear inverse relationship between $\mathrm{P} / \mathrm{S}$ ratio and total intramuscular fat exists for beef, as shown in Figure 2 based on a set of literature data $(n=113)$. Each point in the graph represents a treatment or group mean value. If not reported, the P/S ratio was calculated from the available fatty acid data as mentioned above. Total intramuscular fat mostly refers to the content of total fatty acids and in a few cases to the fat content analysed by another method. An exponential model appeared to give the best fit. Although different breeds and feeding regimes were used in these studies and in spite of analytical differences, the intramuscular fat level accounted for $85 \%$ of the variation in the $\mathrm{P} / \mathrm{S}$ ratio in beef using this model.

Hence, the P/S ratio of beef can drop to a value of 0.05 in fat breeds and can rise to $>0.5$ in very lean breeds (e.g. double-muscled animals). This variation is much larger than what can actually be achieved in beef by alterations in the diet. Apart from using very lean animals, the only way to improve the $\mathrm{P} / \mathrm{S}$ ratio in ruminant meats is by preventing ruminal biohydrogenation or by feeding protected PUFA supplements [78].

In pork, the proportion of PUFA in intramuscular fat is generally higher than in beef and easier to manipulate by dietary factors [92]. Hence, human dietary recommended $\mathrm{P} / \mathrm{S}$ ratio can be approximated in the intramuscular fat of most modern pig breeds when including some source of polyunsaturated fat in the pig's diet. However, variation in the intramuscular fat content can be large between pigs and pig breeds and a decrease in the $\mathrm{P} / \mathrm{S}$ ratio with increasing fatness has also been clearly demonstrated for pork $[4,88]$.

\subsection{Muscle lipid composition}

The effect of fatness on the P/S ratio can be explained to a large extent by differences in the fatty acid composition of the major lipid fractions and the relative contribution of these fractions to total lipids. Muscle lipids are composed of polar lipids, mainly phospholipids located in the cell membranes, and neutral lipids consisting mainly of triacylglycerols in the adipocytes that are 
Table I. Distribution of PUFA in phospholipids (ph) and triacylglycerols (tcg) and the ratio of ph/ tcg in total intramuscular fat of longissimus of beef and pork.

\begin{tabular}{lcccc}
\hline Meat & \% PUFA in ph & \% PUFA in tcg & Ratio ph/tcg & Reference \\
\hline Beef & & & & \\
& $29.2-31.0$ & $1.30-2.0$ & $0.13-0.28$ & {$[8]$} \\
& $38.7-39.7$ & $4.4-5.9$ & $0.37-0.55$ & {$[13]$} \\
& $25.3-37.6$ & $1.39-2.39$ & $0.11-0.13$ & {$[39]$} \\
& 37.3 & 2.4 & 0.10 & {$[49]$} \\
& $40.1-48.8$ & $4.55-6.07$ & $0.65-0.98$ & {$[68]$} \\
& $28.2-30.4$ & $0.95-1.40$ & $0.13-0.16$ & {$[76]$} \\
& $21.5-23.3$ & $1.49-1.67$ & $0.22-0.31$ & {$[77]$} \\
& 32.6 & 3.07 & 0.39 & {$[90]$} \\
& & & & {$[7]$} \\
& $44.7-45.0$ & $9.3-14.5$ & $0.23-0.43$ & {$[20]$} \\
& $43.7-46.9$ & $9.3-13.3$ & $0.44-0.57$ & {$[43]$} \\
& $41.9-42.8$ & $7.26-10.1$ & $0.22-0.23$ & {$[88]$} \\
\hline
\end{tabular}

located along the muscle fibres and in the interfascicular area. A small amount of triacylglycerols is also present as cytosolic droplets in the muscle fibres [24]. The content of phospholipids in the muscle is relatively independent of the total fat content and varies between 0.2 and $1 \%$ of muscle weight. However, the content of muscle triacylglycerols is strongly related to the total fat content and varies from $0.2 \%$ to more than 5\% [21, 24, 81]. Phospholipids are particularly rich in PUFA, whereas triacylglycerols contain much lower amounts of PUFA (Tab. I). Because phospholipids are membrane components, their PUFA proportion is strictly controlled in order to maintain membrane properties. Although the PUFA content of triacylglycerols can be influenced by dietary factors, particularly in monogastrics, it is diluted by de novo fatty acid synthesis consisting of SFA and MUFA, thus causing a decline in the P/S ratio with increasing fat deposition.

Different muscles differ in fat content and may also differ in fatty acid composition. One might question whether this is related to the metabolic fibre type, since it is generally believed that glycolytic muscles contain less fat than oxidative ones. However, Leseigneur-Meynier and Gandemer [41] showed that total intramuscular and triacylglycerol contents are not strictly related to the metabolic fibre type. Glycolytic and oxidative muscles may contain similar amounts of intramuscular fat. Similarly, these authors showed that the fatty acid composition of phospholipids and triacylglycerols is little affected by the metabolic fibre type. On the contrary, the content of phospholipids and the distribution of various classes of phospholipids vary according to the metabolic fibre type. Red oxidative muscles contain more phospholipids, with a higher proportion of phosphatidylethanolamine and cardiolipin, compared to white glycolytic muscles. These differences can be explained by the higher content of organelles, particularly mitochondria, of red muscles and the specific phospholipid class composition of mitochondrial membranes compared to other membranes [24, 41]. Although metabolic fibre type is related to the differences between muscles for several meat quality traits, it does not seem to 
explain much of the differences in fatty acid composition between the muscles. Other factors are thus responsible for the differences in fat content and fatty acid composition between muscles.

\subsection{Effect on $n-6 / n-3$ ratio}

As for the $\mathrm{P} / \mathrm{S}$ ratio, the $\mathrm{n}-6 / \mathrm{n}-3$ ratio of the total lipid fraction may vary depending on the n- $6 / n-3$ ratio of the phospholipid and triacylglycerol fractions, although it is clear that the $n-6 / n-3$ ratios are much more affected by feeding than by genetics, as shown e.g. for pork [20] and for beef [8, 34] and as reviewed by Raes et al. [67]. The C18:2n-6/C18:3n-3 ratio in membrane phospholipids is generally higher than in triacylglycerols, reflecting the preferential deposition of C18:2n-6 in phospholipids and the more equal partitioning of C18:3n-3 in triacylglycerols and phospholipids. Since the amount of longer chain PUFA deposited in triacylglycerols is very low, the C18:2n-6/ C18:3n-3 ratio and the overall $n-6 / n-3$ ratio are very similar in the triacylglycerol fraction. On the contrary, the overall n-6/n-3 ratio of membrane phospholipids is lower than the $\mathrm{C} 18: 2 n-6 / C 18: 3 n-3$ ratio due to the preferential synthesis of longer chain fatty acids of the n-3 series over the n- 6 series. This means that the effect of changes in the phospholipid/triacylglycerol ratio, as a result of changes in the fat level, on the n-6/ $\mathrm{n}-3$ ratio is variable and depends on the diet. For a given diet, the $\mathrm{C} 18: 2 \mathrm{n}-6 / \mathrm{C} 18: 3 \mathrm{n}-3$ ratio in very lean meat will be higher than in meat with a higher fat level. The outcome of variation in the fat level on the overall n-6/n-3 ratio is less marked. Hence, values for the C18:2n-6/C18:3n-3 ratio and overall n-6/ $\mathrm{n}-3$ ratio in longissimus total lipids as low as 2 and 1.3 respectively as reported by Enser et al. [19] for grass-fed steers or lambs, will probably be difficult to achieve in very lean cattle breeds, even when these cattle are fed diets rich in n-3 PUFA. A similar reasoning can be made for pork. In any case, feeding factors have a much larger effect on the $n-6 / n-3$ ratio than genetic effects. This is also illustrated by the absence of any clear relationship when plotting the $n-6 / n-3$ ratio vs. the intramuscular fat content for beef, using the same set of literature data that was used for Figure 1.

The study of Itoh et al. [34] is also worth mentioning in this respect. These authors compared Angus and Simmental steers over a wide range of intramuscular fat levels (between 3 and 18\%) and on different diets. They calculated linear regression relationships between fatty acid proportions in triacylglycerols and phospholipids and the intramuscular lipid content. Within the triacylglycerols, proportions of C18:2n-6 and C18:3n-3 decreased significantly with increasing levels of intramuscular fat, whereas the relationships between individual SFA or MUFA and intramuscular fat content were not significant. For fatty acids in the phospholipids, significantly higher proportions of C16:0, C16:1 and C18:1 and significantly lower proportions of most of the PUFA were found with increasing levels of intramuscular fat. Changes in the overall fatty acid profile with varying lipid levels are thus not solely due to changes in the ratio of phospholipids to triacylglycerols. However, Kazala et al. [37] found an inverse relationship between the relative amount of C18:2n-6 from total lipids and the total lipid content in two different muscle samples from crossbred Wagyu cattle, but this relationship was absent when linoleic acid from the triacylglycerol fraction only was examined. Hence, these authors also concluded that the negative association is due to a dilution of membrane phospholipids with increasing triacylglycerols, as discussed above.

\section{BREED AND SEX DIFFERENCES}

\subsection{Beef}

As mentioned above, breed differences reported in the literature are often confounded by differences in fatness. Several 
authors made corrections for the effect of fatness by including it as a covariate in the statistical analyses or compared breeds at similar carcass fat levels, and still found significant differences in individual fatty acid concentrations between breeds, as well in the triacylglycerol and in the phospholipid fraction. Zembayashi et al. [97] suggested that the Japanese Black has a genetic predisposition for producing lipids with higher MUFA concentrations than other breeds studied. Zembayashi and Nishimura [98] reported significant differences in SFA, MUFA and PUFA proportions of intramuscular triacylglycerols and phospholipids between the progeny of different sires of the Japanese Black breed. These findings were recently confirmed in a study of Oka et al. [59] that compared the intramuscular fatty acid profile of Japanese Black Wagyu steers derived from 34 sires. The Wagyu beef breed is known for its extensive marbling and comparatively less external fat, and has been found to have higher levels of MUFA and a higher MUFA/SFA ratio than other breeds in several studies $[2,17,51,54,84$, $94,95]$. However, the health benefit of the slightly higher MUFA/SFA ratio in these studies is probably counteracted by the very high fat content of this kind of meat and the associated very low $\mathrm{P} / \mathrm{S}$ ratio. The studies above paid little or no attention to the $\mathrm{P} / \mathrm{S}$ ratio.

Breed differences and associated effects of maturity or growth potential on the subcutaneous or intramuscular fatty acid composition of beef were also reported by Gillis et al. [28], Huerta-Leidenz et al. [32, 33], Malau-Aduli et al. [45, 46], Mills et al. [52], Pitchford et al. [63], Rule et al. [73] and Siebert et al. [80]. Sex effects are also reported regularly. At comparable intramuscular fat contents, several authors [17, 37, 97] found a slightly higher MUFA/SFA intramuscular ratio for heifers compared to steers, with no difference in the linoleic acid proportion or P/S ratio. Malau-Aduli et al. [46] found large differences in the phospholipid fatty acid composition between yearling steers and heifers fed on pasture. The phospholi- pid $\mathrm{P} / \mathrm{S}$ ratio was 0.27 for steers versus 0.54 for heifers. This difference appears to be exceptionally large and inconsistent with other literature findings, and the authors do not give any explanation. Eichhorn et al. [15] reported similar fatty acid composition of muscle phospholipids for steers and bulls, and attributed the higher SFA proportion in total lipids from steers to the higher fat to lean ratio. Gillis et al. [28] reported a significantly higher level of linoleic acid and a lower level of oleic acid in subcutaneous and intramuscular fat of bulls compared to steers. The possible effects of sex hormones on the enzyme systems such as $\Delta^{9}$-desaturase may interfere at this point.

Specific breed differences in the $n-6 /$ $\mathrm{n}-3$ ratio and in the levels of longer chain fatty acids C20:5n-3 and C22:6n-3 that probably could not be attributed to differences in the fat level have also been reported. Choi et al. [8] reported significantly higher proportions of C18:3n-3 in triacylglycerols and phospholipids and higher proportions of C20:5n-3 and C22:5n-3 in phospholipids of Welsh Black compared with Holstein Friesians, resulting in a lower $n-6 / n-3$ ratio in Welsh Black. The content of C20:5n-3 was also significantly higher in phospholipids of Welsh Blacks, but there were no differences in the contents of C18:3n-3 and C22:6n-3. This preferential deposition of $\mathrm{n}$-3 PUFA was maintained on diets containing supplemental n-3 PUFA, hence no evidence of breed by diet interaction was present. Itoh et al. [34] found significant differences between Angus and Simmental in the deposition of C18:3n-3 and of the longer chain fatty acids, but breed $x$ diet interactions were present for some of the fatty acids, making it difficult to interpret the breed effects. Also Laborde et al. [38] found differences in total and individual n-3 fatty acids in the longissimus muscle when Red Angus and Simmental steers were compared, while no breed effects were detected for individual and total n-6 PUFA.

Although interesting, it should be stressed that many of these breed and sex differences 
are relatively small and are, although often statistically significant, probably of little value from a nutritional viewpoint. Nevertheless, they reflect the underlying differences in gene expression or activities of enzymes involved in fatty acid synthesis, desaturation or chain elongation, and therefore deserve further attention.

\subsection{Pork}

Cameron and Enser [4] and Cameron [3] compared Duroc and halothane-negative British Landrace pigs for their intramuscular fatty acid composition. The Duroc breed is known for its high intramuscular fat content relative to the backfat content compared with other breeds. In line with the above considerations, the intramuscular SFA and MUFA proportions were higher and the PUFA proportions were lower for Duroc than for British Landrace pigs. No correction was made for the higher fat content of the Duroc breed in this study, since this was considered to be a breed effect. It thus remains unclear whether the Duroc breed would reveal different fatty acid proportions at similar fat levels compared to Landrace breeds.

Cameron et al. [7] studied the genotype by nutrition interactions on fatty acid composition of intramuscular fat in Large White pigs. Pigs from four selected lines (seven generations of selection for high daily food intake, lean food conversion ratio and lean growth rate on ad libitum or restricted feeding regimes) and a control line were fed different diets on either restricted or ad libitum feeding regimes. There were selection line effects on the fat content and on the fatty acid composition of triacylglycerols and phospholipids, but the diet effects were larger than the selection line effects, especially on the $n-6 / n-3$ ratio. More importantly, there was no evidence of genotype with nutrition interactions.

Sex differences have also been examined by several authors for pork fatty acid composition [4, 30, 88, 89]. Muscle phos- pholipid fatty acid composition does not seem to differ between gilts and barrows, but higher PUFA concentrations have repeatedly been found in total lipid or triacylglycerols for gilts, even after correction for differences in fat content. Hence, as stated for breed effects, residual sex effects independent of fat content seem to exist for fatty acid composition.

\section{MAJOR GENES}

\subsection{Double-muscling in beef}

The Belgian Blue beef breed is well known for its extreme carcass leanness, due to the high selection effort on conformation and to the associated high frequency of double-muscled animals caused by a mutation in the myostatin gene. The lean nature of Belgian Blue meat and the accompanying high $\mathrm{P} / \mathrm{S}$ ratio in the intramuscular fat has been shown in several studies $[9,10,12,13$, 90]. In addition to the high ratio of phospholipids to triacylglycerols contributing to the high P/S ratio, the PUFA content of the phospholipid fraction also seems to be higher in double-muscled animals compared to other literature data (Tab. I, $[13,67,90])$. On the contrary, the amount of phospholipids on a fresh meat weight basis is lower in double-muscled animals, in line with the more glycolytic fibre type of these animals. Raes et al. [66] examined the intramuscular fatty acid composition in the three myostatin genotypes (double-muscling, $\mathrm{mh} / \mathrm{mh}$; heterozygous, $\mathrm{mh} /+$; normal, $+/+$ ). The markedly higher $\mathrm{P} / \mathrm{S}$ ratio for the doublemuscled animals compared with the normal ones may be explained by their lower fat content in line with the general discussion above. The heterozygous genotype had intermediate fatty acid contents compared to the two homozygous genotypes. Other effects on the n-3 and the n- 6 metabolism related to the myostatin genotype were also observed (Fig. 3). The content of C18:3n-3 on a tissue basis was significantly lower for 

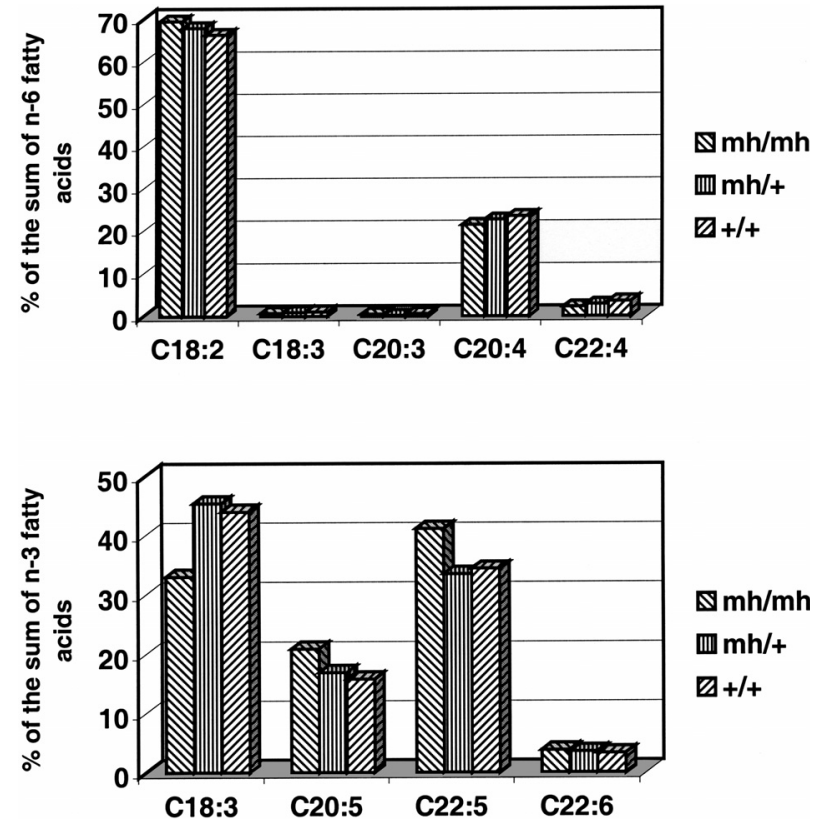

Figure 3. The effect of the myostatin genotype on the n-6 (above) and the n-3 (below) polyunsaturated fatty acid metabolims (data obtained from [66]).

the $m h / m h$ genotype than for the $+/+$ genotype, whereas the contents of C20:5n-3, C22:5n-3 and C22:6n-3 were higher or similar. Hence, a myostatin genotype effect on the n-3 and n-6 PUFA metabolism is suggested. $\mathrm{Mh} / \mathrm{mh}$ animals had significantly higher proportions of $\mathrm{C} 20: 5 \mathrm{n}-3$ and C22:5n-3 relative to the sum of n-3 PUFA compared with the other genotypes. Conversely, the proportions of $\mathrm{C} 20: 4 \mathrm{n}-6$ and C22:4n- 6 relative to the sum of n- 6 PUFA were higher for the $+/+$ genotype than for the $\mathrm{mh} / \mathrm{mh}$ genotype.

Raes et al. [66] also looked at the effect of the double-muscled genotype on the conjugated linoleic acids (CLA) content in meat. CLA have received a lot of attention in recent research because of their potential beneficial effects on health. CLA refers to a group of positional and geometric isomers of octadecaenoic acid with a conjugated double bond system, of which the c9t11 and t10c12 isomers are the most abundant. Both isomers are naturally found in ruminant derived food products, formed as intermediates during the biohydrogenation of linoleic acid in the rumen. However, endogenous synthesis of c9t11CLA is the predominant production pathway in the mammary gland [29], and also occurs in the subcutaneous or intramuscular fat by the action of $\Delta^{9}$-desaturase on $111 \mathrm{C} 18: 1$, which is produced in the rumen [65]. Genetic differences in $\Delta^{9}$-desaturase activity might thus lead to differences in c9t11CLA content. The c9t11CLA content on a muscle basis was about three times higher for the +/+ genotype than for the $\mathrm{mh} /$ $m h$ genotype, but on a proportionate basis the c9t11CLA content did not vary much between genotypes (approximately $0.45 \mathrm{~g}$ per $100 \mathrm{~g}$ fat) [66]. In a recent study using 
double-muscled bulls, the c9t11CLA content was positively related to the total intramuscular fatty acid content [68], corresponding to the fact that CLA are mainly found in the triacylglycerol fraction. In line with the absence of a double-muscled genotype effect [66], no effect of breed on the CLA content of beef was found by Laborde et al. [38] and Mir et al. [54]. However, breed differences for the CLA content in milk and a large variation in the CLA content of milk of individual cows have been found [40, 42]. In addition, these authors showed significant correlation coefficients between milk CLA contents of individual cows at repeated samplings, suggesting some genetic variability.

\subsection{Pork}

Honkavaara [31] and Piedrafita et al. [62] found only minor effects of the stress susceptibility genotype on the subcutaneous and intramuscular fatty acid profile of pigs. Hartmann et al. [30], however, found a significantly higher $\mathrm{P} / \mathrm{S}$ ratio in muscle and adipose tissue for stress-susceptible pigs compared to normal pigs, but the authors also reported highly significant inverse relationships between the $\mathrm{P} / \mathrm{S}$ ratio and total lipid content in different tissues. Hence, the genotype effect might have been the result of a difference in fat content. Otten et al. [60] studied the effect of a high vs. a low n-3 fatty acid diet on the lipid composition of heart and skeletal muscle in normal and stress-susceptible pigs. The pattern of n-3 fatty acid incorporation was different between normal and stress-susceptible pigs, and the authors concluded that the interaction between the diet-induced n-3 fatty acid profile and stress genotype may indicate a repair mechanism to maintain cellular functions in stress-susceptible pigs. Johansson et al. [36] reported relatively small differences in fatty acid composition for pigs with and without the $\mathrm{RN}^{-}$allele. In pigs, polymorphisms in the H-FABP gene have been associated with variability in intramuscular fat content, largely independent of backfat thickness [25, 26], but to our knowledge no reports on the possible changes in fatty acid composition are available yet. Interestingly, in a QTL mapping study using an $\mathrm{F}_{2}$ cross between Iberian $\times$ Landrace pigs, PérezEnciso et al. [61] concluded that the metabolism and(or) deposition rate of linoleic acid is under (partial) control of a QTL on chromosome 4, and that the effect of the QTL was not an artifact caused by the differences in backfat thickness.

\section{QUANTITATIVE GENETICS}

Reports of genetic parameters for fatty acid composition traits are scarce. Pitchford et al. [63] reported estimates of genetic parameters for carcass traits and fatty acid proportions in adipose tissue samples (subcutaneous and muscle) of crossbred cattle (Hereford dams $\times$ seven sire breeds). Heritability estimates for individual fatty acids and their summations, desaturation and elongation indices, melting point and marbling were low to moderate (0.14-0.33). Genetic correlations between fatty acid composition and carcass traits were not significant in this study, allowing the authors to conclude that simultaneous improvement in carcass and meat quality traits is feasible. In a related study, Malau-Aduli et al. [47] reported high genetic correlations between fatty acid proportions in biopsy samples collected at weaning and samples taken at slaughter.

For pork, heritabilities and genetic correlations for subcutaneous and intramuscular fatty acid composition and carcass and eating quality traits were estimated in a population of Duroc and halothane negative British Landrace boars and gilts by Cameron [3] and Cameron and Enser [4]. Heritabilities of intramuscular fat content (0.53) and other objectively measured meat quality traits were in line with literature data. Heritabilities for the major subcutaneous fatty acid (C16:0, C18:0, C18:1 and $\mathrm{C} 18: 2 \mathrm{n}-6)$ proportions were high and varied between 0.53 and 0.71 . The heritability 
estimates for the intramuscular fatty acids were between 0.25 and 0.50 , except for C18:0 and C18:3n-3 with values of 0.73 and 0.62 respectively. The proportions of C16:0, C18:0 and C18:1 were negatively correlated with carcass lean weight at both the genetic and the phenotypic level, whereas the proportion of C18:2n-6 showed opposite correlations, for the inner layer of subcutaneous fat as well as for intramuscular fat. Sellier [79] reviewed the genetics of meat and carcass traits and came to similar conclusions for backfat fatty acid characteristics.

The level of the heritabilities and genetic correlations reported theoretically allow for the induction of changes in fatty acid composition by direct or indirect selection. However, the value of incorporating one or more fatty acid composition traits as such in classical breeding programs may be questioned at the present for several reasons. Fatty acid composition is not a single trait and it is not clear at present which and how many fatty acids or derived parameters should be included as criteria in a breeding program. When looking at the $\mathrm{P} / \mathrm{S}$ ratio as one of the possible criteria, the favourable correlation with fatness suggests that an improved P/S ratio can probably be more easily obtained following indirect selection for lower fatness levels than through direct selection for individual fatty acids. In addition, measuring fatty acid composition on a large number of animals for breeding value estimation is not evident at the present at a reasonable cost. Gibson [27] similarly concluded that there is a biological potential for genetic changes in milk fat composition, but that for several reasons it is probably not interesting to include it as a goal in conventional breeding programmes. However, if more insight could be obtained in the genetic variability of the biochemical processes determining differences in fatty acid composition in farm animals, e.g. genetic bases for differences in elongase and desaturase enzyme activities, a molecular genetic approach could offer possibilities for genetic improvement in the future.

\section{ENZYME ACTIVITIES}

Some authors determined enzyme activities in subcutaneous adipose tissue or calculated indices for enzyme activities from fatty acid composition data in order to explain the observed variability in fatty acid composition. A $\mathrm{C} 16$ and $\mathrm{C} 18$ desaturation index is sometimes calculated as $[\mathrm{C} 16: 1 /(\mathrm{C} 16: 0+\mathrm{C} 16: 1)] 100$ and $[\mathrm{C} 18:$ 1n-9/(C18:0+C18:1n-9)]100 respectively. Stearoyl-CoA or $\Delta^{9}$ desaturase is the terminal step in the desaturation and the conversion of myristic, palmitic and stearic acid into the $\Delta^{9}$ monounsaturated fatty acids myristoleic, palmitoleic and oleic acid respectively. As mentioned above, some Japanese cattle breeds are known for their excessive marbling and their relatively high MUFA content. Sturdivant et al. [84] postulated that the higher MUFA levels reflected an elevated $\Delta^{9}$ desaturase activity. Cameron et al. [6] measured stearoyl-CoA desaturase enzyme activities and mRNA concentrations in subcutaneous adipose samples from Angus and American Wagyu steers. Enzyme activities and mRNA concentrations were not significantly different between the two breeds, and could thus not explain the higher MUFA proportion in the Wagyu breed. Wilson et al. [91] described a TaqI restriction fragment length polymorphism in the stearoyl-CoA desaturase gene in DNA from pure-bred Japanese Black cattle, and later reported the potential differences in the allelic frequency. To our knowledge, no information is available yet on the differences in meat producing animals for the activities of the $\Delta^{5}$ and $\Delta^{6}$ desaturase enzymes that are responsible for the desaturation steps in the synthesis of the longer chain (C20-C24) fatty acids.

The synthesis of fatty acids longer than 16 carbons takes place in microsomes and involves the elongation by two-carbon additions in a series of sequential reactions. An elongation index is sometimes calculated as $[(\mathrm{C} 18: 0+\mathrm{C} 18: 1 \mathrm{n}-9) /(\mathrm{C} 16: 0+$ C16:1+C18:0+C18:1n-9)]100. A negative 
relationship between the elongation index and the intramuscular fat content was reported in two studies, at the phenotypic level on beef from Wagyu crossbred cattle [37] and at the genetic level on crossbred cattle [63]. Kazala et al. [37] suggested that fatty acid elongation was unable to keep pace with the de novo production of palmitic acid in animals that deposited greater amounts of intramuscular fat. However, based on tissue incubations, it was suggested that $\Delta^{9}$ desaturation and not elongation was the rate-limiting step for the conversion of palmitic to oleic acid in bovine subcutaneous adipose tissue [82].

Cameron et al. [5] measured fatty acid synthetase and lipoprotein lipase activities of subcutaneous fat in sheep from the lines of Texel-Oxford and Scottish Blackface, both divergently selected for carcass lean content. Fatty acid synthetase and lipoprotein lipase activity were measured to reflect de novo fatty acid synthesis and uptake of exogenous fatty acids by adipocytes respectively. Breed or selection line had no effect on the subcutaneous fatty acid composition. Fatty acid synthetase activity was different between the two breeds, but not between selection lines. Lipoprotein lipase activities were not different between the breeds and selection lines. Lipoprotein lipase activity was positively related to the backfat depth and lipid content of subcutaneous fat. Barber et al. [1] investigated the expression of a number of lipogenic enzyme genes in different ovine adipose tissue depots. Based on the differences in the relationships between the abundance of mRNA per adipocyte and the amount of C18:1 per adipocyte and the adipocyte mean cell volume, these authors concluded that the stearoylCoA desaturase gene seems to be regulated in a depot-specific fashion and in a manner distinct from that of other lipogenic enzyme genes. Expression of the stearoyl-CoA desaturase gene varied with adipocyte cell size for carcass depots and was positively correlated with the amount of C18:1 per cell. However, the expression of this gene in the abdominal fat depots did not vary sig- nificantly with adipocyte cell volume, probably contributing to the lower amount of C18:1 per cell and the lower C18:1/C18:0 ratio in the abdominal fat compared with carcass depots. Several other studies have examined the activities of lipogenic enzymes in relation to fat deposition and marbling, but did not measure fatty acid composition and are therefore not considered here.

At this moment, information on enzyme activities and expression of genes involved in fatty acid synthesis and metabolism is too limited to explain between-animal genetic variability in fatty acid composition. Hence, biochemical and molecular genetic studies in this field should be encouraged to unravel the mechanisms underlying the differences between the genotypes in the metabolism and incorporation of specific fatty acids.

\section{CONCLUSIONS}

Meat fatty acid composition is, besides the predominant effect of nutrition, related to the level of fatness, reflecting de novo fatty acid synthesis and the balance between triacylglycerols and phospholipids in meat. In beef, the P/S ratio is mainly determined by the level of fatness and increases with low intramuscular fat content. In pork, the $\mathrm{P} / \mathrm{S}$ ratio is generally higher than in beef and nutrition plays a more important role. No general relationship between the level of fatness and the n- $6 / n-3$ ratio in meat can be expected due to the overriding effect of the dietary $n-6 / n-3$ ratio. Independent of fatness, genetic variation between breeds and specific genotypes seem to exist for the synthesis and incorporation of individual fatty acids, which deserve more attention at the biochemical and molecular genetic level.

\section{ACKNOWLEDGMENTS}

Part of our own research dealt with in this review was made possible with financial support from the Ministry of the Flemish Community, Brussels and the EU Community (project QLRT-2000-31423, Healthy Beef). 


\section{REFERENCES}

[1] Barber M.C., Ward R.J., Richards S.E., Salter A.M., Buttery P.J., Vernon R.G., Travers M.T., Ovine adipose tissue monounsaturated fat content is correlated to depot-specific expression of the stearoyl-CoA desaturase gene, J. Anim. Sci. 78 (2000) 62-68.

[2] Boylston T.D., Morgan S.A., Johnson K.A., Busboom J.R., Wright R.W., Reefes J.J., Lipid content and composition of Wagyu and domestic breeds of beef, J. Agric. Food Chem. 43 (1995) 1202-1207.

[3] Cameron N.D., Genetic and phenotypic parameters for fatty acid composition of subcutaneous fat, meat quality, carcass composition and eating quality traits in pigs, Proc. 4th WCGALP, Edinburgh, UK, Vol. XV, 1990, pp. 549-552.

[4] Cameron N.D., Enser M., Fatty acid composition of lipid in longissimus dorsi muscle of Duroc and British Landrace pigs and its relationship with eating quality, Meat Sci. 29 (1991) 295-307.

[5] Cameron N.D., Bishop S.C., Speake B.K., Bracken J., Noble R.C., Lipid composition and metabolism of subcutaneous fat in sheep divergently selected for carcass lean content, Anim. Prod. 58 (1994) 237-242.

[6] Cameron P.J., Rogers M., Oman J., May S.G., Lunt D.K., Smith S.B., Stearoyl coenzyme A desaturase enzyme activity and mRNA levels are not different in subcutaneous adipose from Angus and American Wagyu steers, J. Anim. Sci. 72 (1994) 2624-2628.

[7] Cameron N.D., Enser M., Nute G.R., Whittington F.M., Penman J.C., Fisken A.C., Perry A.M., Wood J.D., Genotype with nutrition interaction on fatty acid composition of intramuscular fat and the relationship with flavour of pig meat, Meat Sci. 55 (2000) 187195.

[8] Choi N.J., Enser M., Wood J.D., Scollan N.D., Effect of breed on the deposition in beef muscle and adipose tissue of dietary n-3 polyunsaturated fatty acids, Anim. Sci. 71 (2000) 509-519.

[9] Clinquart A., Istasse L., Dufrasne I.K., Mayombo A., Van Eenaeme C., Bienfait J.M., Effects on animal performance and fat composition of two fat concentrates in diets for growing-fattening bulls, Anim. Prod. 53 (1991) 315-320.

[10] Clinquart A., Van Eenaeme C., Van Vooren T., Van Hoof J., Hornick J.-L., Istasse L., Meat quality in relation to breed (Belgian Blue vs. Holstein) and conformation (double muscled vs. dual purpose type), Sci. Aliments 14 (1994) 401-407.

[11] Clinquart A., Van Eenaeme C., Dufrasne I., Gielen M., Istasse L., Soya oil in the diet of growing-fattening bulls. II. Effects on metabolism in the rumen, apparent digestibility, plasma hormones and metabolites, J. Anim. Physiol. Anim. Nutr. 74 (1995) 15-23.

[12] Clinquart A., Hornick J.L., Van Eenaeme C., Istasse L., Influence du caractère culard sur la production et la qualité de la viande des bovins Blanc Blue Belge, INRA Prod. Anim. 11 (1998) 285-297.

[13] De Smet S.,WebbE.C., Claeys E., Uytterhaegen L., Demeyer D.I., Effect of dietary energy and protein levels on fatty acid composition of intramuscular fat in double-muscled Belgian Blue bulls, Meat Sci. 56 (2000) 73-79.

[14] Demeyer D., Doreau M., Targets and procedures for altering ruminant meat and milk lipids, Proc. Nutr. Soc. 58 (1999) 593-607.

[15] Eichhorn J.M., Baily C.M., Blomquist G.J., Fatty acid composition of muscle and adipose tissue from crossbred bulls and steers, J. Anim. Sci. 61 (1985) 892-904.

[16] Eichhorn J.M., Coleman L.J., Wakayama E.J., Blomquist C., Bailey M., Jenkins T.G., Effects of breed type and restricted versus ad libitum feeding on fatty acid composition and cholesterol content of muscle and adipose tissue of mature bovine females, J. Anim. Sci. 63 (1986) 781-794.

[17] Elias Calles J.A., Gaskins C.T., Busboom J.R., Duckett S.K., Cronrath J.D., Reeves J.J., Sire variation in fatty acid composition of crossbred Wagyu steers and heifers, Meat Sci. 56 (2000) 23-29.

[18] Enser M., Hallett K., Hewitt B., Fursey G.A.J., Wood J.D., Fatty acid content and composition of English beef, lamb and pork at retail, Meat Sci. 42 (1996) 443-456.

[19] Enser M., Hallett K., Hewitt B., Fursey G.A.J., Wood J.D., Harrington G., Fatty acid content and composition of UK beef and lamb muscle in relation to production system and implications for human nutrition, Meat Sci. 49 (1998) 329-341.

[20] Enser M., Richardson R.I., Wood J.D., Gill B.P., Sheard P.R., Feeding linseed to increase the n-3 PUFA of pork: fatty acid composition of muscle, adipose tissue, liver and sausages, Meat Sci. 55 (2000) 201-212.

[21] Fernandez X., Monin G., Talmant A., Mourot J., Lebret B., Influence of intramuscular fat content on the quality of pig meat -1 . Composition of the lipid fraction and sensory 
characteristics of $m$. longissimus lumborum, Meat Sci. 53 (1999) 59-65.

[22] Fisher A.V., Enser M., Richardson R.I., Wood J.D., Nute G.R., Kurt E., Sinclair L.A., Wilkinson R.G., Fatty acid composition and eating quality of lamb types derived from four diverse breed $\times$ production systems, Meat Sci. 55 (2000) 141-147.

[23] French P., Stanton C., Lawless E.G., O'Riordan E.G., Monahan F.J., Caffrey P.J., Moloney A.P., Fatty acid composition, including conjugated linoleic acid, of intramuscular fat from steers offered grazed grass, grass silage or concentrate-based diets, J. Anim. Sci. 78 (2000) 2849-2855.

[24] Gandemer G., Lipids and meat quality: lipolysis, oxidation, Maillard reaction and flavour, Sci. Aliments 19 (1999) 439-458.

[25] Gerbens F., van Erp A.J.M., Harders F.L., Verburg F.J., Meuwissen T.H.E., Veerkamp J.H., te Pas M.F.W., Effect of genetic variants of the heart fatty acid-binding protein gene on intramuscular fat and performance traits in pigs, J. Anim. Sci. 77 (1999) 846-852.

[26] Gerbens F., de Koning D.J., Harders F.L., Meuwissen T.H.E., Janss L.L.G., Groenen M.A.M., Veerkamp J.H., Van Arendonk J.A.M., te Pas M.F.W., The effect of adipocyte and heart fatty acid-binding protein genes on intramuscular fat and backfat content in Meishan crossbred pigs, J. Anim. Sci. 78 (2000) 552-559.

[27] Gibson J.P., The potential for genetic change in milk fat composition, J. Dairy Sci. 74 (1991) 3258-3266.

[28] Gillis A.T., Eskin N.A.M., Cliplef R.L., Fatty acid composition of bovine intramuscular and subcutaneous fat as related to breed and sex, J. Food Sci. 38 (1973) 408-411.

[29] Griinari J.M., Corl B.A., Lacy S.H., Chouinard P.Y., Nurmela K.V.V., Bauman D.E., Conjugated linoleic acid is synthesised endogenously in lactating dairy cows by $\Delta^{9}$-desaturase, J. Nutr. 130 (2000) 2285-2291.

[30] Hartmann S., Otten W., Kratzmair M., Seewald M.J., Iaizzo P.A., Eichinger H.M., Influences of breed, sex, and susceptibility to malignant hyperthermia on lipid composition of skeletal muscle and adipose tissue in swine, Am. J. Vet. Res. 58 (1997) 738-743.

[31] Honkavaara M., Einflu $\beta$ der Stre $\beta$ empfindlichkeit und Rasse von Schweinen auf die Fettsäurenprofile der subkutanen und intramuskulären Gesamtlipide, Fleischwirtsch. 69 (1989) 1484-1488.
[32] Huerta-Leidenz N.O., Cross H.R., Savell J.W., Lunt D.K., Baker J.F., Pelton L.S., Smith S.B., Comparison of the fatty acid composition of subcutaneous adipose tissue from mature Brahman and Hereford cows, J. Anim. Sci. 71 (1993) 625-630.

[33] Huerta-Leidenz H.O., Cross H.R., Savell J.W., Lunt D.K., Baker J.R., Smith S.B., Fatty acid composition of subcutaneous adipose tissue from male calves at different stages of growth, J. Anim. Sci. 74 (1996) 1256-1264.

[34] Itoh M., Johnson C.B., Cosgrove G.P., Muir P.D., Purchas R.W., Intramuscular fatty acid composition of neutral and polar lipids for heavy-weight Angus and Simmental steers finished on pasture or grain, J. Sci. Food Agric. 79 (1999) 821-827.

[35] Jakobsen K., Dietary modifications of animal fats: status and future perspectives, Fett/Lipid 101 (1999) S475-S483.

[36] Johansson L., Lundstrom K., Jonsall A., Effects of RN genotype and silage feed on fat content and fatty acid composition of fresh and cooked pork loin, Meat Sci. 60 (2002) 1724.

[37] Kazala E.C., Lozeman F.J., Mir P.S., Laroche A., Bailey D.R.C., Weselake R.J., Relationship of fatty acid composition to intramuscular fat content in beef from crossbred Wagyu cattle, J. Anim. Sci. 77 (1999) 1717-1725.

[38] Laborde F.L., Mandell I.B., Tosh J.J., Wilton J.W., Buchanan-Smith J.G., Breed effects on growth performance, carcass characteristics, fatty acid composition and palatability attributes in finishing steers, J. Anim. Sci. 79 (2001) 355-365.

[39] Larick D.K., Turner B.E., Influence of finishing diet on the phospholipid composition and fatty acid profile of individual phospholipids in lean muscle of beef cattle, J. Anim. Sci. 67 (1989) 2282-2293.

[40] Lawless F., Stanton C., L'Escop P., Devery R., Dillon P., Murphy J.J., Influence of breed on bovine milk cis-9, trans-11-conjugated linoleic acid, Livest. Prod. Sci. 62 (1999) 43 49.

[41] Leseigneur-Meynier A., Gandemer G., Lipid composition of pork muscle in relation to the metabolic type of the fibres, Meat Sci. 29 (1991) 229-241.

[42] Lock A.L., Garnsworthy P.C., Independent effects of dietary linoleic and linolenic fatty acids on the conjugated linoleic acid content of cows' milk, Anim. Sci. 74 (2002) 163176. 
[43] Lopez-Bote C.J., Sanz M., Isabel B., Perez de Ayala P., Flores A., Effect of dietary lard on performance, fatty acid composition and susceptibility to lipid peroxidation in growingfinishing female and entire male pigs, Can. J. Anim. Sci. 77 (1997) 301-306.

[44] Madron M.S., Peterson D.G., Dwyer D.A., Corl B.A., Baumgard L.H., Beermann D.H., Bauman D.E., Effect of extruded full-fat soybeans on conjugated linoleic acid content of intramuscular, intermuscular and subcutaneous fat in beef steers, J. Anim. Sci. 80 (2002) 1135-1143.

[45] Malau-Aduli A.E.O., Siebert B.D., Bottema C.D.L., Pitchford W.S., A comparison of the fatty acid composition of triacylglycerols in adipose tissue from Limousin and Jersey cattle, Aust. J. Agric. Res. 48 (1997) 715-722.

[46] Malau-Aduli A.E.O., Siebert B.D., Bottema C.D.K., Pitchford W.S., Breed comparison of the fatty acid composition of muscle phospholipids in Jersey and Limousin cattle, J. Anim. Sci. 76 (1998) 766-773.

[47] Malau-Aduli A.E.O., Edriss M.A., Siebert B.D., Bottema C.D.K., Deland M.P.B., Pitchford W.S., Estimates of genetic parameters for triacylglycerol fatty acids in beef cattle at weaning and slaughter, J. Anim. Physiol. A Anim. Nutr. 83 (2000) 169-180.

[48] Mandell I.B., Buchanan-Smith J.G., Holub B.J., Campbell C.P., Effects of fish meal in beef cattle diets on growth performance, carcass characteristics and fatty acid composition of longissimus muscle, J. Anim. Sci. 75 (1997) 910-919.

[49] Marmer W.N., Maxwell R.J., Williams J.E., Effects of dietary regimen and tissue site on bovine fatty acid profiles, J. Anim. Sci. 59 (1984) 109-121.

[50] Marschall D.M., Genetics of meat quality, in: Fries R., Ruvinsky A. (Eds.), The genetics of cattle, CAB International, Wallingford, UK, 1999, pp. 605-636.

[51] May S.G., Sturdivant C.A., Lunt D.K., Miller R.K., Smith S.B., Comparison of sensory characteristics and fatty acid composition between Wagyu crossbred and Angus steers, Meat Sci. 35 (1993) 289-298.

[52] Mills E.W., Comerford J.W., Hollender R., Harpster H.W., House V., Henning W.R., Meat composition and palatability of Holstein and beef steers as influenced by forage type and protein source, J. Anim. Sci. 70 (1992) 2446-2451.

[53] Mitchell G.E., Reed A.W., Rogers S.A., Influence of feeding regimen on the sensory qualities and fatty acid contents of beef steaks, J. Food Sci. 56 (1991) 1102-1103.

[54] Mir Z., Paterson L.J., Mir P.S., Fatty acid composition and conjugated linoleic acid content of intramuscular fat in crossbred cattle with and without Wagyu genetics fed a barleybased diet, Can. J. Anim. Sci. 80 (2000) 195197.

[55] Nürnberg K., Grumbach S., Papstein H.-J., Matthes H.-D., Ender K., Nürnberg G., Fatty acid composition of lamb meat, Fett/Lipid 98 (1996) 77-80.

[56] Nürnberg K., Wegner J., Ender K., Factors influencing fat composition in muscle and adipose tissue of farm animals, Livest. Prod. Sci. 56 (1998) 145-156.

[57] Nürnberg K., Ender B., Papstein H.J., Wegner J., Ender K., Nurnberg G., Effects of growth and breed on the fatty acid composition of muscle lipids in cattle, $\mathrm{Z}$. Lebensm. Unters. Forsch. 208 (1999) 332-335.

[58] Nürnberg K., Nürnberg G., Ender K., Lorenz S., Winkler K., Rickert R., Steinhart H., n-3 fatty acids and conjugated linoleic acids of longissimus muscle in beef cattle, Eur. J. Lipid Sci. Technol. 104 (2002) 463-471.

[59] Oka A., Iwaki F., Dohgo T., Ohtagaki S., Noda M., Shiozaki T., Endoh O., Ozaki M., Genetic effects on fatty acid composition of carcass fat of Japanese Black Wagyu steers, J. Anim. Sci. 80 (2002) 1005-1011.

[60] Otten W., Iaizzo P.A., Eichinger H.M., Effects of a high n-3 fatty acid diet on membrane lipid composition of heart and skeletal muscle in normal swine and in swine with the genetic mutation for malignant hyperthermia, J. Lipid Res. 38 (1997) 2023-2034.

[61] Pérez-Enciso M., Clop A., Noguera J.L., Óvilo C., Coll A., Folch J.M., Babot D., Estany J., Oliver M.A., Díaz I., Sánchez A., A QTL on pig chromosome 4 affects fatty acid metabolism: evidence from an Iberian by Landrace intercross, J. Anim. Sci. 78 (2000) 2525-2531.

[62] Piedrafita J., Christian L.L., Lonergan S.M., Fatty acid profiles in three stress genotypes of swine and relationships with performance, carcass and meat quality traits, Meat Sci. 57 (2001) 71-77.

[63] Pitchford W.S., Deland M.P.B., Siebert B.D., Malau-Aduli A.E.O., Bottema C.D.K., Genetic variation in fatness and fatty acid composition of crossbred cattle, J. Anim. Sci. 80 (2002) 2825-2832.

[64] Pyle C.A., Bass J.J., Duganzich D.M., Payne E., The fatty acid composition of the subcutaneous brisket fat from steers obtained from 
Angus cows mated to 13 different beef breeds, J. Agric. Sci. (Camb.) 89 (1977) 571-574.

[65] Raes K., Optimisation of the fatty acid composition of beef and eggs: influence of feed and animal factors, Ph.D. thesis, Ghent University, 2003.

[66] Raes K., De Smet S., Demeyer D., Effect of double-muscling in Belgian Blue young bulls on the intramuscular fatty acid composition with emphasis on conjugated linoleic acid and polyunsaturated fatty acids, Anim. Sci. 73 (2001) 253-260.

[67] Raes K., De Smet S., Demeyer D., Effect of dietary fatty acids on incorporation of long chain polyunsaturated fatty acids and conjugated linoleic acid in lamb, beef and pork meat: a review, Anim. Feed Sci. Technol. 113 (2004) 199-221.

[68] Raes K., De Smet S., Balcaen A., Claeys E., Demeyer D., Effect of diets rich in n-3 polyunsaturated fatty acids on muscle lipids and fatty acids in Belgian Blue double-muscled young bulls, Reprod. Nutr. Dev. 43 (2003) 331-345.

[69] Raes K., Balcaen A., Dirinck P., De Winne A., Claeys E., Demeyer D., De Smet S., Meat quality, fatty acid composition and flavour analysis of Belgian retail beef, Meat Sci. 65 (2003) 1237-1247.

[70] Raes K., Haak L., Balcaen A., Claeys E., Demeyer D., De Smet S., Effect of linseed feeding at similar linoleic acid levels on the fatty acid composition of double-muscled Belgian Blue young bulls, Meat Sci. 66 (2004) 307-315.

[71] Rey A.I., Kerry J.P., Lynch P.B., López-Bote C.J., Buckley D.J., Morrissey P.A., Effect of dietary oils and $\alpha$-tocopheryl acetate supplementation on lipid (TBARS) and cholesterol oxidation in cooked pork, J. Anim. Sci. 79 (2001) 1201-1208.

[72] Riley P.A., Enser M., Nute G.R., Wood J.D., Effects of dietary linseed on nutritional value and other quality aspects of pig muscle and adipose tissue, Anim. Sci. 71 (2000) 483500 .

[73] Rule D.C., MacNeil M.D., Short R.E., Influence of sire growth potential, time on feed, and growing-finishing strategy on cholesterol and fatty acids of the ground carcass and Longissimus muscle of beef steers, J. Anim. Sci. 75 (1997) 1525-1533.

[74] Rule D.C., Broughton K.S., Shellito S.M., Maiorano G., Comparison of muscle fatty acid profiles and cholesterol concentrations of bison, beef cattle, elk and chicken, J. Anim. Sci. 80 (2002) 1202-1211.
[75] Sañudo C., Enser M.E., Campo M.M., Nute G.R., Maria G., Sierra I., Wood J.D., Fatty acid composition and sensory characteristics of lamb carcasses from Britain and Spain, Meat Sci. 54 (2000) 339-346.

[76] Scollan N.D., Choi N.J., Kurt E., Fisher A.V., Enser M., Wood J.D., Manipulating the fatty acid composition of muscle and adipose tissue in beef cattle, Brit. J. Nutr. 85 (2001) $115-124$

[77] Scollan N.D., Cooper A., Evans P., Enser M., Richardson R.I., Nute G.R., Fisher A.V., Wood J.D., Effect of forage legumes on the fatty acid composition of beef and other aspects of meat quality, Proceedings of the 48th International Congress of Meat Science and Technology, Rome, Italy, Vol. I, 2002, pp. 356-357.

[78] Scollan N.D., Enser M., Gulati S.K., Richardson I., Wood J.D., Effects of including a ruminally protected lipid supplement in the diet on the fatty acid composition of beef muscle, Brit. J. Nutr. (2003) 709-716.

[79] Sellier P., Genetics of meat and carcass traits, in: Rothschild M.F., Ruvinsky A. (Eds.), The genetics of the pig, CAB International, Wallingford, UK, 1998, pp. 463-510.

[80] Siebert B.D., Deland M.P., Pitchford W.S., Breed differences in the fatty acid composition of subcutaneous and intramuscular lipid of early and late maturing, grain-finished cattle, Aust. J. Agric. Res. 47 (1996) 943-952.

[81] Sinclair A.J., O’Dea K., Fats in human diets through history: is the Western diet out of step, in: Wood J.D., Fisher A.V. (Eds.), Reducing fat in meat animals, Elsevier Applied Science, London, UK, 1990, pp. 1-47.

[82] St. John L.C., Lunt D.K., Smith S.B., Fatty acid elongation and desaturation enzyme activities of bovine liver and subcutaneous adipose tissue microsomes, J. Anim. Sci. 69 (1991) 1064-1073.

[83] Strzetelski J., Kowalczyk J., Osieglowski S., Stasiniewicz T., Lipiarska E., Pustkowiak H., Fattening bulls on maize silage and concentrate supplemented with vegetable oils, J. Anim. Feed Sci. 10 (2001) 259-271.

[84] Sturdivant C.A., Lunt D.K., Smith G.C., Smith S.B., Fatty acid composition of subcutaneous and intramuscular adipose tissues and $M$. longissimus dorsi of Wagyu cattle, Meat Sci. 32 (1992) 449-458.

[85] Thompson J.M., Ball A.J., Genetics of meat quality, in: Piper L., Ruvinsky A. (Eds.), The genetics of sheep, CAB International, Wallingford, UK, 1997, pp. 523-538. 
[86] Vatansever L., Kurt E., Enser M., Nute G.R., Scollan N.D., Wood J.D., Richardson R.I., Shelf life and eating quality of beef from cattle of different breeds given diets differing in n-3 polyunsaturated fatty acid composition, Anim. Sci. 71 (2000) 471-482.

[87] Vernon R.G., Flint D.F., Lipid metabolism in farm animals, Proc. Nutr. Soc. 47 (1988) 287-293.

[88] Warnants N., Van Oeckel M.J., Boucqué C.V., Incorporation of dietary polyunsaturated fatty acids in pork tissues and its implications for the quality of the end products, Meat Sci. 44 (1996) 125-144.

[89] Warnants N., Van Oeckel M.J., Boucqué C.V., Incorporation of dietary polyunsaturated fatty acids into pork fatty tissues, $\mathrm{J}$. Anim. Sci. 77 (1999) 2478-2490.

[90] Webb E.C., De Smet S., Van Nevel C., Martens B., Demeyer D.I., Effect of anatomical location on the composition of fatty acids in double-muscled Belgian Blue cows, Meat Sci. 50 (1998) 45-53.

[91] Wilson J.J., Zembayashi M., Lunt D.K., Smith S.B., Rapid communication: A TaqI restriction fragment length polymorphism in the stearoyl-CoA desaturase gene in DNA from purebred Japanese Black cattle, J. Anim. Sci. 71 (1993) 2575.

[92] Wood J.D., Enser M., Factors influencing fatty acids in meat and the role of antioxi- dants in improving meat quality, Brit. J. Nutr. 78 (Suppl. 1) (1997) 49-60.

[93] Wood J.D., Enser M., Fisher A.V., Nute G.R., Richardson R.I., Sheard P.R., Manipulating meat quality and composition, Proc. Nutr. Soc. 58 (1999) 363-370.

[94] Xie Y.R., Busboom J.R., Gaskins C.T., Johnson K.A., Reeves J.J., Wright R.W., Cronrath J.D., Effects of breed and sire on carcass characteristics and fatty acid profiles of crossbred Wagyu and Angus steers, Meat Sci. 43 (1996) 167-177.

[95] Yang A., Larsen T.W., Powell V.H., Tume R.K., A comparison of fat composition of Japanese and long-term grain-fed Australian steers, Meat Sci. 51 (1999) 1-9.

[96] Yang A., Lanari M.C., Brewster M., Tume R.K., Lipid stability and meat colour of beef from pasture- and grain-fed cattle with or without vitamin E supplement, Meat Sci. 60 (2002) 41-50.

[97] Zembayashi M., Nishimura K., Lunt D.K., Smith S.B., Effect of breed type and sex on the fatty acid composition of subcutaneous and intramuscular lipids of finishing steers and heifers, J. Anim. Sci. 73 (1995) 33253332 .

[98] Zembayashi M., Nishimura K., Genetic and nutritional effects on the fatty acid composition of subcutaneous and intramuscular lipids of steers, Meat Sci. 43 (1996) 83-92. 